\title{
Coumarin derivatives: Synthesis and cation binding properties
}

\author{
Olfa Naouali ${ }^{1}$, Rached Frija ${ }^{3}$, Wissal Elgabsi ${ }^{3}$, Naceur Hamdi ${ }^{2,3, *}$ and Lassaad Baklouti ${ }^{1,2^{*}}$ \\ ${ }^{1}$ Laboratory of Applied Chemistry and Natural Substances Resources and Environment, Faculty of Sciences, \\ University of Carthage, Zarzouna-Bizerta, 7021, Tunisia \\ ${ }^{2}$ Chemistry Department, College of Science and Arts, Qassim University, Al-Rass, Kingdom of Saudi Arabia \\ ${ }^{3}$ Heterocyclic and Organometallic Chemistry Laboratory, Higher Institute of Environmental Sciences and \\ Technology, University of Carthage, Hammam-Lif, 2050, Tunisia
}

\begin{abstract}
Coumarin derivatives were easily prepared starting from 7-hydroxy 4-methyl-2H-chromen-2-one with $40 \%$ formaldehyde and suitable secondary amines in $95 \%$ ethanol in rather good yield. The structures of all compounds were confirmed via spectroscopic techniques IR, ${ }^{1} \mathrm{H}$ NMR, ${ }^{13} \mathrm{C}$ NMR, mass spectra and elemental analysis. The complexing properties of the coumarin derivatives toward alkali metal, alkaline earth metal, some transition metals and some heavy metal cations have been investigated in methanol by means of UV spectrophotometry absorption and conductivity methods. Thus, the stoichiometry of the complexes formed and their stability constants were determined.
\end{abstract}

Keywords: Mannich bases; Stability constants; Coumarin derivatives; UV spectrophotometry; Cation binding properties; 7-hydroxy 4-methyl-2H-chromen-2-one.

\section{Introduction}

While the Mannich reaction is an organic reaction used to convert a primary or secondary amine and two carbonyl compounds (one non-enolizable and one enolizable) to a $\beta$-amino carbonyl compound, also known as a Mannich base, using an acid or base catalyst, in a variant of the reaction the enolizable carbonyl component can be replaced with an electronrich aromatic system, which is also called an aminomethylation of an arene. Mannich bases can display varied biological activities such as antimicrobial ${ }^{1-5}$, cytotoxic $^{6-13}$, anticancer ${ }^{14,15}$, anti-inflammatory ${ }^{16,17}$ and anticonvulsant ${ }^{18,19}$ and DNA topoisomerase properties ${ }^{20,21}$.

In this work, novel aminomethylcoumarin derivatives have been synthesized. Their complexation of alkali metal, alkaline earth metal and transition metal cations, and the liquid liquid extraction of metallic picrate salts by coumarin derivatives $\mathbf{2}, \mathbf{3}$ and $\mathbf{5}$ were investigated, also. Efforts to quantify the complexation equilibrium were based on the use of UV spectrophotometry, although conductometric measurements were also used to obtain preliminary estimates of the stoichiometry of complexes formed. 


\section{Results and Discussion}

The Mannich bases 2-3 were prepared starting from 7-hydroxy 4-methyl-2H-chromen2-one 1 with $40 \%$ formaldehyde and suitable secondary amines in $95 \%$ ethanol in rather good yield $^{22}$ (Scheme 1).<smiles>Cc1cc(=O)oc2cc(O)ccc12</smiles>

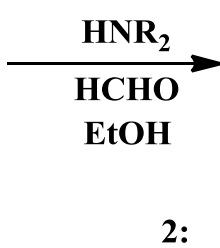<smiles>[Y9]=[W]</smiles><smiles>[R16]Cc1c(O)ccc2c(C)cc(=O)oc12</smiles>

3: $\quad \mathrm{NR}_{2}=$<smiles>CN1C=CNCC1</smiles>

\section{Scheme 1}

The ${ }^{1} \mathrm{H}$ NMR spectrum of compound 2 displayed the $\mathrm{CH}_{2}$ protons as a singlet at $\delta 4.05 \mathrm{ppm}$, the piperidine protons as multiplets between $\delta 1.96-1.37 \mathrm{ppm}$, the $\mathrm{H} 3$ of the coumarin ring as a singlet at $\delta 6.09 \mathrm{ppm}$ and finally the aromatic protons as different multiplets at $\delta 6.77$ to $7.46 \mathrm{ppm}$.

In the infrared, compound 3 showed two peaks at around 3220 due to $\mathrm{OH}$ vibration. The $\mathrm{OH}$ proton of compound $\mathbf{2}$ appeared at $\delta 12.38 \mathrm{ppm}$.

The acetylation of 4-hydroxycoumarin to give 3-acetyl- 4-hydroxycoumarin 5 was carried out by the method of Dholakia et al. [23] by using glacial acetic acid in the presence of $\mathrm{POCl}_{3}$. The quick reaction led to the desired product without obtaining any product from the intramolecular condensation of 4-hydroxycoumarin. Scheme 2 [24,25].<smiles>O=c1cc(O)c2ccccc2o1</smiles>

4

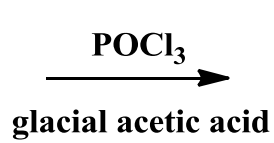

Scheme 2<smiles>CC(=O)c1c(O)c2ccccc2oc1=O</smiles>

This compound was characterized by IR, ${ }^{1} \mathrm{H}$ and ${ }^{13} \mathrm{C}$ NMR. The ${ }^{1} \mathrm{H}$ NMR shows that aromatic proton arrow as a multiplet between 7.24 and $8.01 \mathrm{ppm}$. A singlet at $2.74 \mathrm{ppm}$ was assigned to methylic proton whilst the $\mathrm{OH}$ signal appeared at $17.72 \mathrm{ppm}$. This very high value of the chemical shift might be explained only by an intermolecular hydrogen bond. We became concerned about the identity of this compound and therefore carried out an X-ray crystal structure determination, in order to establish the structure unambiguously ${ }^{26}$.

\section{Complexation of metal cations in methanol}

The logarithms of the stability constants $\log \beta_{\mathrm{xy}}$ and the stoichiometries of the different complexes formed by compounds $\mathbf{2}, \mathbf{3}$ and $\mathbf{5}$ with alkali metals, alkaline-earth metals and some transition metals in methanol are given in Tables 1 and 2. 
Table 1: Stability Constants $\log \beta x y$ of the complexes of $2, \mathbf{3}$ and $\mathbf{5}$ with alkali and alkaline earth cations in methanol at $25^{\circ} \mathrm{C}, \mathrm{I}=10^{-2} \mathrm{M},\left(0.01 \leq \sigma_{\mathrm{n}-1} \leq 0.05\right)$.

\begin{tabular}{lllllllllll}
\hline & $\mathbf{M}: \mathbf{L}$ & $\mathbf{L i}^{+}$ & $\mathbf{N a}^{+}$ & $\mathbf{K}^{+}$ & $\mathbf{R b}^{+}$ & $\mathbf{C s}^{+}$ & $\mathbf{M g}^{\mathbf{2 +}}$ & $\mathbf{C a}^{2+}$ & $\mathbf{S r}^{\mathbf{2 +}}$ & $\mathbf{B a}^{\mathbf{2 +}}$ \\
\hline $\mathbf{2}$ & $1: 1$ & 3.43 & 2.06 & 3.01 & 2.10 & 3.09 & 2.33 & 2.21 & 2.54 & 2.65 \\
$\mathbf{3}$ & $1: 1$ & 2.86 & 2.51 & 2.74 & 2.80 & 3.01 & 3.30 & 2.45 & 2.73 & 2.95 \\
$\mathbf{5}$ & $1: 1$ & 2.80 & 2.70 & 2.46 & 2.60 & 2.80 & 2.90 & 2.40 & 3.10 & 2.80 \\
\hline
\end{tabular}

Table 2: Stability Constants $\log \beta$ xy of the Complexes of 2, 3, 5 with some transition and heavy metals in methanol at $25^{\circ} \mathrm{C}, \mathrm{I}=10^{-2} \mathrm{M} .\left(0.01 \leq \sigma_{\mathrm{n}-1} \leq 0.05\right)$.

\begin{tabular}{lllllllll}
\hline & $\mathbf{M}: \mathbf{L}$ & $\mathbf{C o}^{\mathbf{2 +}}$ & $\mathbf{C u}^{\mathbf{2 +}}$ & $\mathbf{Z n}^{\mathbf{2 +}}$ & $\mathbf{S n}^{\mathbf{2 +}}$ & $\mathbf{M n}^{\mathbf{2 +}}$ & $\mathbf{N i}^{\mathbf{2 +}}$ & $\mathbf{F e}^{\mathbf{3 +}}$ \\
\hline $\mathbf{2}$ & $1: 1$ & 4.10 & 4.40 & 3.03 & 4.19 & 3.60 & 3.60 & $\mathrm{a}$ \\
$\mathbf{3}$ & $1: 1$ & 4.30 & 4.02 & 3.48 & 3.10 & 3.61 & 3.09 & $\mathrm{a}$ \\
$\mathbf{5}$ & $1: 1$ & 4.60 & 4.70 & 3.97 & 3.80 & 4.10 & 3.04 & $\mathrm{a}$ \\
\hline
\end{tabular}

a: Absorbance changes too small to enable satisfactory fitting.

The selectivity profile of compound $\mathbf{2}$ in the series of alkali and alkaline-earth cations, showsan affinity for lithium, whereas the affinity is in favor of magnesium with compound $\mathbf{3}$ and for strontium with compound 5 (Figures1-2).
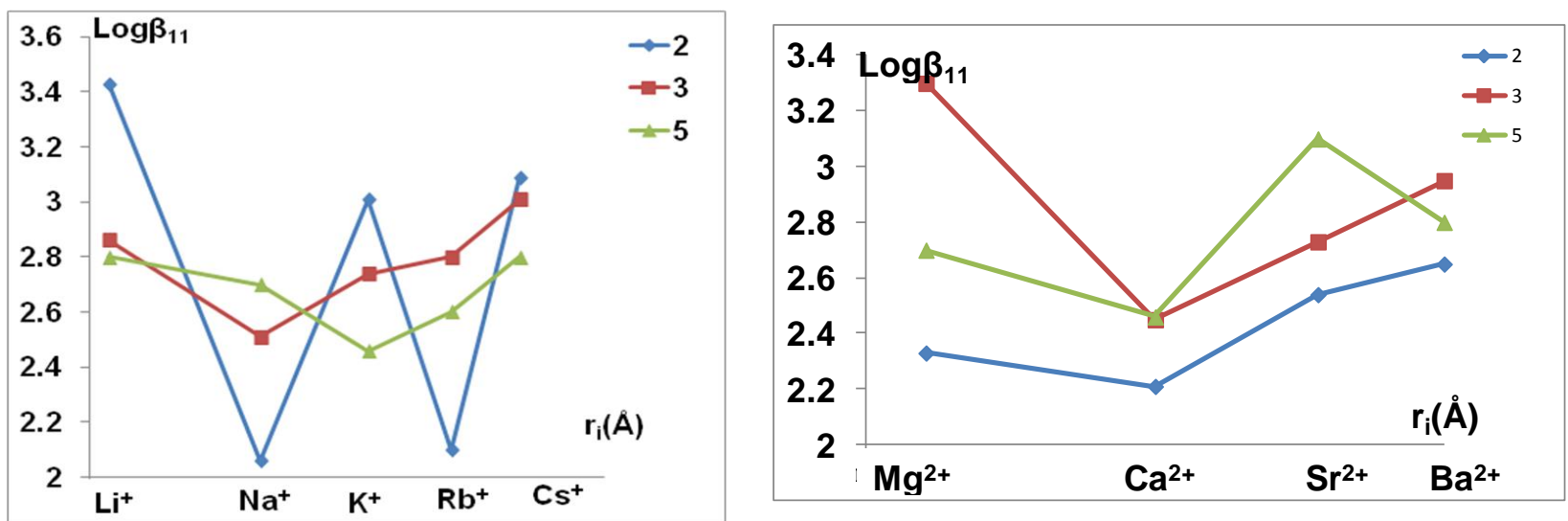

Figure 1: Stability constants $\log \beta_{11}$ (determined in methanol) for (left) alkali and (right) alkaline earth cations with 2, 3 and $\mathbf{5}$.
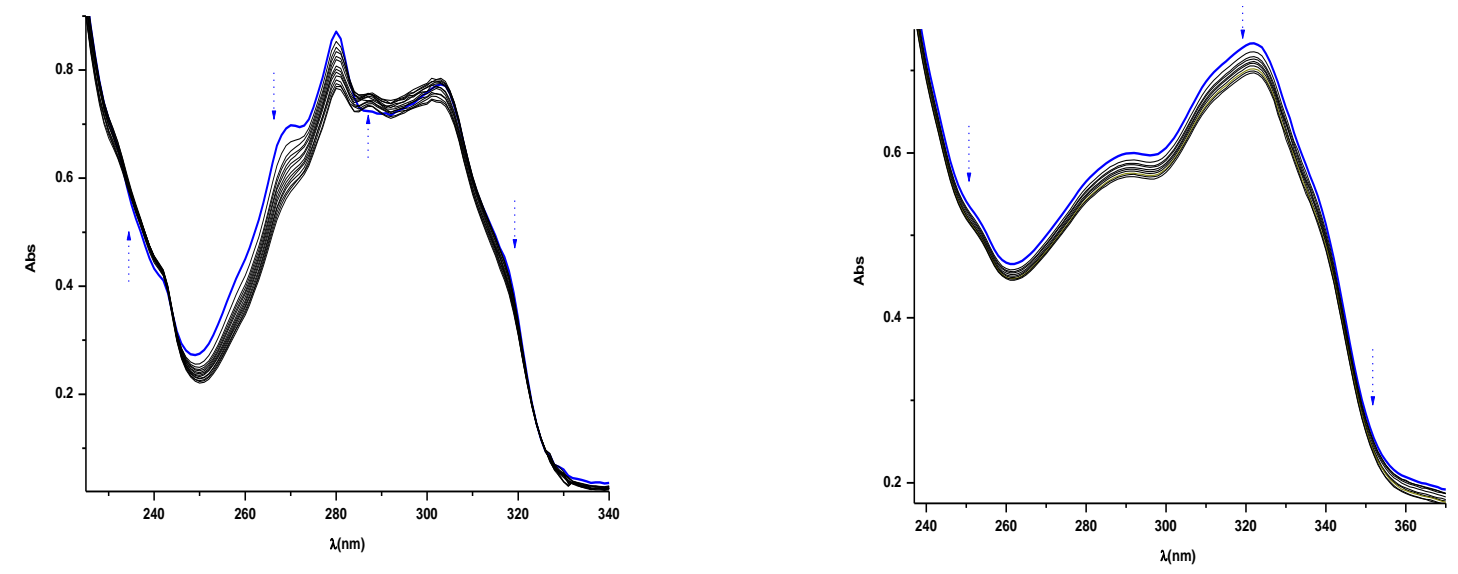

Figure 2: UV absorption spectra on complexation of (left) $\mathrm{Li}^{+}$with 2 in methanol (right) of $\mathrm{Na}^{+}$with 5 in methanol. $\left(0 \leq \mathrm{R}_{\mathrm{M} / \mathrm{L}} \leq 9\right)$ at $25^{\circ} \mathrm{C}$. 
Moreover, the selectivity profiles suggest that the size of the cations is a dominant factor in the complexation.

The selectivity profile of compounds $\mathbf{2}$ and $\mathbf{5}$ in the transition metal series shows an affinity for cobalt and cuprite complexes in methanol, while there is an affinity for cobalt with ligand 3 (Figure 3). On the other hand, the stability of the complexes formed with compound 5 are of the same order of magnitude, which shows that the complexation is not affected by the size effect in the series of transition metal cations considered.

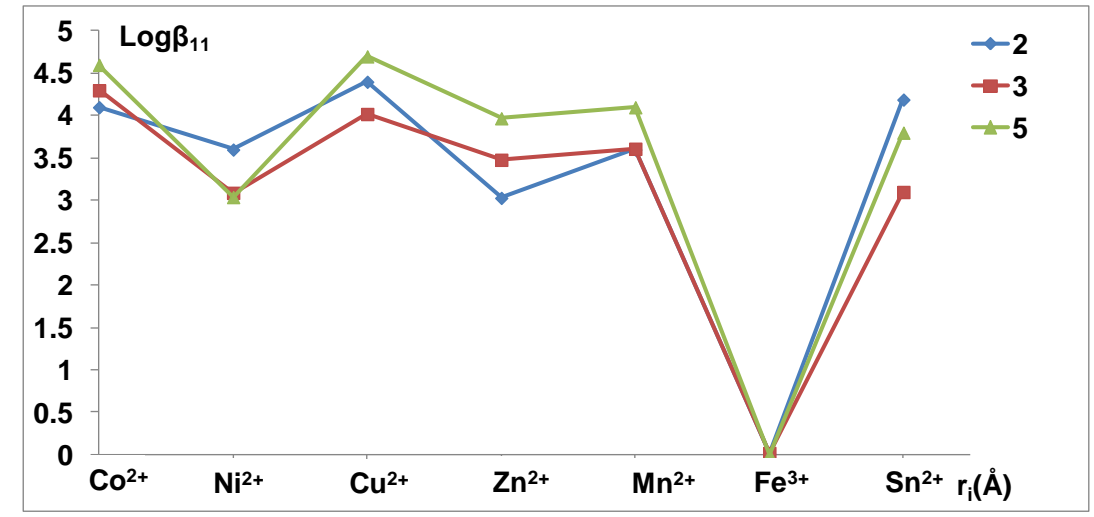

Figure 3: Stability constants $\log \beta_{11}$ (determined in methanol) for some transition metal and heavy metal cations with $\mathbf{2 , 3 , 5}$

Generally, the stability constant of the transition metal complexes is greater with copper than with alkali and alkaline earth cations. The coumarin derivatives $\mathbf{2}, \mathbf{3}$ and $\mathbf{5}$ has no complexation affinity to Fe(III) (Figure 4).
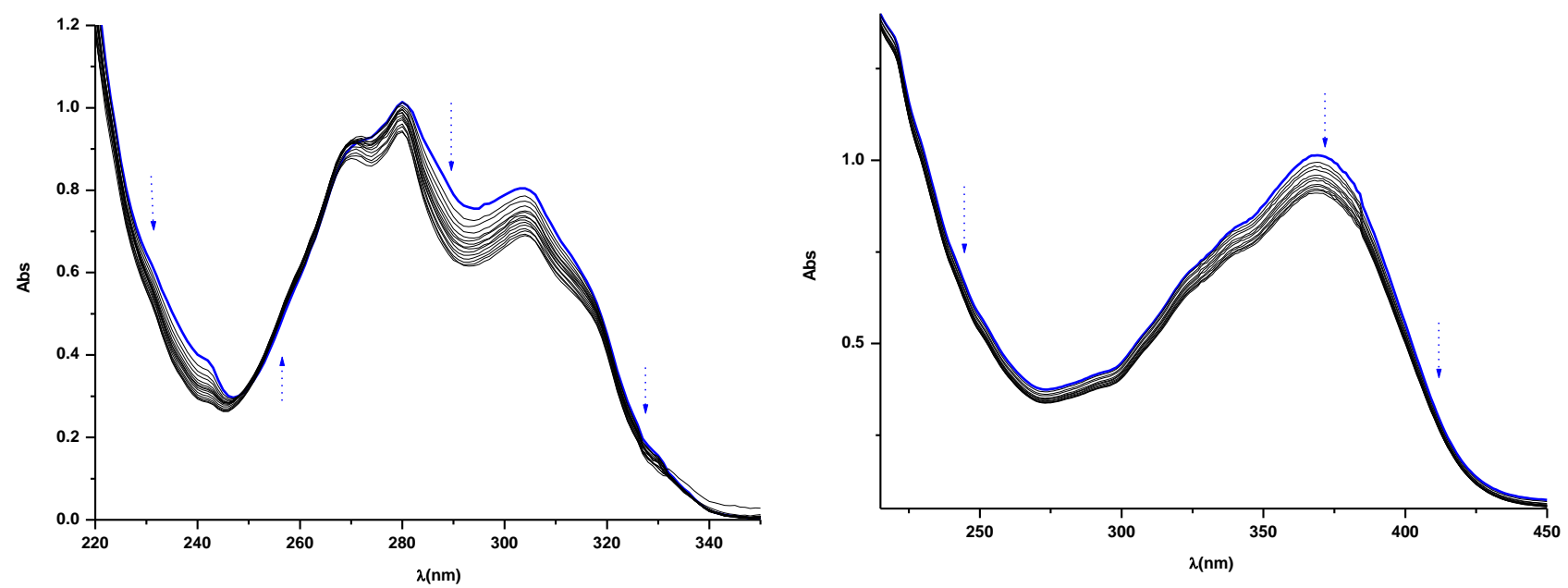

Figure 4: UV absorption spectra on complexation of (left) $\mathrm{Zn}^{2+}$ with 2 in methanol and (right) $\mathrm{Sn}^{2+}$ with 3 in methanol $(0 \leq \mathrm{RM} / \mathrm{L} \leq 6)$ at $25^{\circ} \mathrm{C}$.

Furthermore, the stoichiometries of 1:1 for the complexes with the compounds $\mathbf{2}, \mathbf{3}$ and $\mathbf{5}$ were confirmed by conductometric titration in some cases (Figure 5). 


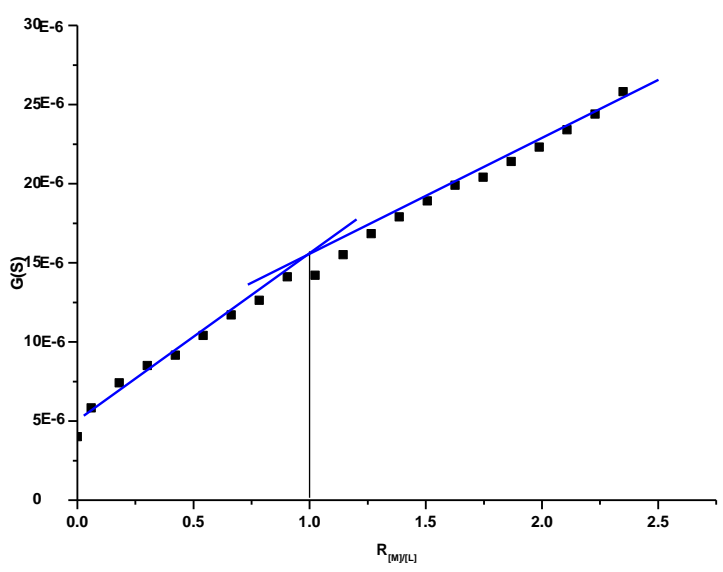

Figure 5: Conductometric titration in the case of 2 with $\mathrm{Cu}^{2+}$

\section{Extraction of metal picrates}

A preliminary evaluation of the binding efficiency of Mannich base derivatives has been carried out by solvent extraction of metal picrates into dichloromethane at $20^{\circ} \mathrm{C}$ under neutral conditions. The extraction percentages $(\% \mathrm{E})$ of some transition metal picrates by compounds $\mathbf{2}, \mathbf{3}$ and $\mathbf{5}$ from water into dichloromethane are given in Table $\mathbf{3}$.

Table 3: Extraction Percentages (\%E) of some transition metal picrates by 2, 3 and $\mathbf{5}$ from Water into dichloromethane, at $25^{\circ} \mathrm{C}\left(\mathrm{CL}=\mathrm{CM}=2.5 \times 10^{-4} \mathrm{~mol} \mathrm{~L}^{-1}\right)$.

\begin{tabular}{llllllll}
\hline & $\mathbf{C o}^{\mathbf{2 +}}$ & $\mathbf{N i}^{\mathbf{2 +}}$ & $\mathbf{C u}^{\mathbf{2 +}}$ & $\mathbf{Z n}^{\mathbf{2 +}}$ & $\mathbf{M n}^{\mathbf{2 +}}$ & $\mathbf{F e}^{\mathbf{3 +}}$ & $\mathbf{P b}^{\mathbf{2 +}}$ \\
\hline $\mathbf{2}$ & 14 & 10 & 18 & $\leq 1$ & 10 & $\leq 1$ & 23 \\
$\mathbf{3}$ & 37 & 23 & 45 & 12 & 37 & $\leq 1$ & 33 \\
$\mathbf{5}$ & 36 & 28 & 32 & 20 & 29 & 12 & 35 \\
\hline
\end{tabular}

In the series of transition metals, ligand 2 extracts notably $\mathrm{Pb}^{2+}$ with a percentage of $23 \%$. Whereas, the $\% \mathrm{E}$ obtained with ligand $\mathbf{3}$ was $45 \%$ for $\mathrm{Cu}$ (II). For ligand $\mathbf{5}$, the $\% \mathrm{E}$ obtained can be up to $36 \%$ with Co (II).

Ligand $\mathbf{3}$ is a better extractant than compounds $\mathbf{2}$ and $\mathbf{5}$. This is due to the presence of the methyl methylpiperazine moiety.

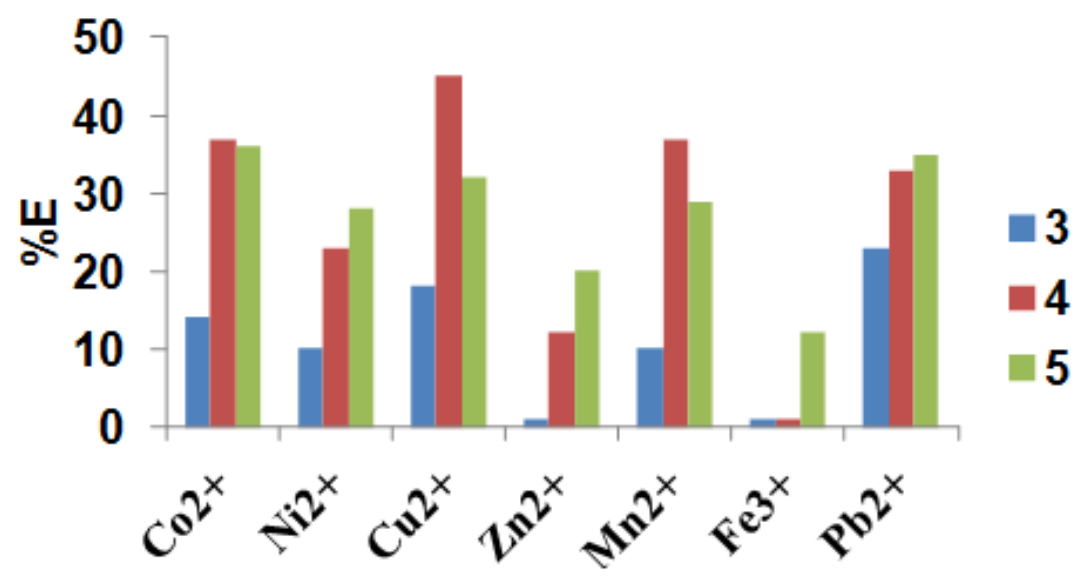

Figure 6: Trends of the extraction percentages $(\% \mathrm{E})$ for some transition metal and heavy metal picrates from water into dichloromethane with 2, 3 and 5 . 


\section{Conclusion}

In this study, three novel coumarin derivatives were synthesized. The structures of these products were confirmed by their spectral data. The results show the formation of mononuclear species to a ligand $\mathbf{2 , 3}$ and $\mathbf{5}$ complex with metals studied. The conductometric titration confirmed mainly the stoichiometries of the complexes formed in solution with $\mathbf{2}, \mathbf{3}$ and 5 determined by the UV spectrophotometry study.

However, the extraction study shows a lower extraction affinity for the metal picrates with compound 2. This ligand extracts only $\mathrm{Pb}$ (II) and $\mathrm{Cu}$ (II). Ligand 3 extracts $\mathrm{Cu}$ (II) and ligand 5 extracts preferably $\mathrm{Co}$ (II) in the series of the considered picrate salts. The complexation power of compounds $\mathbf{2 , 3}$ and $\mathbf{5}$ is not correlated with the extraction results.

\section{Acknowledgements}

Authors would like to thank Qassim University for their encouragement and support of this work via our project SEBEK.

\section{Experimental Section}

\section{General}

Melting points were determined using an Electrothermal apparatus and are uncorrected. ${ }^{1} \mathrm{H}$ NMR and ${ }^{13} \mathrm{C}$ NMR spectra were carried on a Varian Gemini 200 (200 MHz) spectrometer using TMS as internal standard $(\delta=0 \mathrm{ppm})$. IR spectra were recorded on a Perkin-Elmer 398 Spectrophotometer. Elemental analyses were performed on Perkin-Elmer 2400 elemental analyzer, and the values found were within $\pm 0.3 \%$ of the theoretical values. The UV spectra were recorded on a Perkin Elmer Lambda 11 spectrophotometer. Methanol (Riedel-de Haën for HPLC) and dichloromethane (Fluka, purum) were commercial and used without further purification. The supporting electrolyte used in the stability constant determinations was $\mathrm{NEt}_{4} \mathrm{Cl}$ (Acros Organics). The metal salts chosen were chlorides (Fluka, purum). The picrate salts employed in extraction were prepared as described in the literature ${ }^{27}$.

\section{Synthesis of compound 2 and 3}

To $20.0 \mathrm{mmol}$ of 4-methyl-7-hydroxycoumarin dissolved in $50 \mathrm{~mL}$ of ethanol, $20.0 \mathrm{mmol}$ of the appropriate amine and $2.0 \mathrm{~mL}$ of $40 \%$ formaldehyde were added. The resulting mixture was refluxed for $6 \mathrm{~h}$. After cooling, the solvent was evaporated under reduced pressure. The pale yellow oil obtained was treated with cool acetone, leaving a white solid which was crystallized from acetone obtaining 7-hydroxy-4-methyl-8-(piperidin-1ylmethyl)-2H-chromen-2-one (2) and 7-hydroxy-4-methyl-8-((4-methylpiperazin-1-yl) methyl)-2H-chromen-2-one (3), respectively.

\section{7-Hydroxy-4-methyl-8-(piperidin-1-ylmethyl)-2H-chromen-2-one (2):}

M.p.: $169-170{ }^{\circ} \mathrm{C}$.

Yield: $62.0 \%$.

FT-IR (KBr, v, $\left.\mathrm{cm}^{-1}\right): 2600,1722,1600,1580$.

${ }^{1} \mathrm{H}$ NMR (300 MHz, $\mathrm{CDCl}_{3}, \delta, \mathrm{ppm}$ ): 1.96-1.37 (m, 13H, $\mathrm{CH}_{3}+$ Piperidinyl), 4.05 (s, 2H, $\left.\mathrm{CH}_{2}\right), 6.09$ (s, $\left.1 \mathrm{H}, \mathrm{H}_{3}\right), 6.77$ (d, $\left.J=7.8 \mathrm{~Hz}, 1 \mathrm{H}, \mathrm{Ar}-\mathrm{H}\right), 7.46(\mathrm{~d}, J=7.8 \mathrm{~Hz}, 1 \mathrm{H}, \mathrm{Ar}-\mathrm{H})$, 
$12.38(\mathrm{~s}, 1 \mathrm{H}, \mathrm{OH}) .{ }^{13} \mathrm{C} \mathrm{NMR}\left(75 \mathrm{MHz}, \mathrm{CDCl}_{3}, \delta, \mathrm{ppm}\right): 24.5\left(\mathrm{CH}_{3}\right), 25.6(\mathrm{C}-13,15)$, 26.6 (C-14), 39.5 (C11), 52.1 (C-12,16), 109.5 (C-3), 112.1 (C-6), 116.3 (C-8), 120.6 (C-10), 126.5 (C-5), 152.1 (C-9), 155.6 (C-4), 162.5 (C2), 157.2 (C-7),

\section{7-Hydroxy-4-methyl-8-((4-methylpiperazin-1-yl)methyl)-2H-chromen-2-one (3):}

M.p.: $132-134{ }^{\circ} \mathrm{C}$.

Yield: $55 \%$.

IR $\left(\mathrm{KBr}, v, \mathrm{~cm}^{-1}\right): 3502,2953,2823,1727,1279$.

${ }^{1} \mathrm{H}$ NMR $\left(300 \mathrm{MHz}, \mathrm{DMSO}-d_{6}, \delta, \mathrm{ppm}\right): 2.65\left(\mathrm{~s}, 3 \mathrm{H}, 4-\mathrm{CH}_{3}\right), 3.25\left(\mathrm{~s}, 3 \mathrm{H},-\mathrm{N}-\mathrm{CH}_{3}\right)$, 4.00-4.37 (m, 8H, piperazinyl), 4.99 (s, 2H, $\left.\mathrm{CH}_{2}\right), 6.68\left(\mathrm{~s}, 1 \mathrm{H}, \mathrm{H}_{3}\right), 7.30(\mathrm{~d}, J=9 \mathrm{~Hz}, 1 \mathrm{H}$, Ar-H), 8.02 (d, $J=9 \mathrm{~Hz}, 1 \mathrm{H}, \mathrm{Ar}-\mathrm{H}), 12.25$ (s, 1H, OH).

${ }^{13} \mathrm{C}$ NMR $\left(75 \mathrm{MHz}, \mathrm{CDCl}_{3}, \delta, \mathrm{ppm}\right): 24.5\left(\mathrm{CH}_{3}\right), 39.5(\mathrm{C} 11), 38.7\left(\mathrm{~N}-\mathrm{CH}_{3}\right), 109.5(\mathrm{C}-3)$, 155.6 (C-4), 162.5 (C2), 126.5 (C-5), 112.1 (C-6), 157.2 (C-7), 116.3 (C-8), 152.1 (C-9), 120.6 (C-10), 55.1 (C-12), 58.4 (C-13).

\section{Synthesis of 3-acetyl-4-hydroxy-2H-chromen-2-one (5)}

To a mixture of 4-hydroxy- $2 \mathrm{H}$-chromen-2-one (3 g, $1.86 \mathrm{mmol})$ and acetic acid (16 $\mathrm{mL})$ was added phosphorus oxychloride $(5.6 \mathrm{~mL})$. Then, the solution was heated at reflux for 30 min. After cooling, the precipitate was collected and recrystallized from ethanol to give 3acetyl-4-hydroxy-2H-chromen-2-one as white needles.

M.p.: $135-138{ }^{\circ} \mathrm{C}$.

Yield: $2.7 \mathrm{~g}(90 \%)$.

IR $\left(\mathrm{KBr}, v, \mathrm{~cm}^{-1}\right): 3185,1705,1700$.

${ }^{1} \mathrm{H}$ NMR (300 MHz, $\left.\mathrm{CDCl}_{3}, \delta, \mathrm{ppm}\right): 2.72\left(\mathrm{~s}, 3 \mathrm{H}, \mathrm{CH}_{3}\right), 7.98(\mathrm{~s}, 1 \mathrm{H}, \mathrm{Ar}-\mathrm{H}), 7.95$ (dd, $1 \mathrm{H}$, $\left.J=7.80,8.35,{ }^{4} J=6.80,1.20 \mathrm{~Hz}, \mathrm{Ar}-\mathrm{H}\right), 7.1-7.4(\mathrm{~m}, 2 \mathrm{H}, \mathrm{Ar}-\mathrm{H}), 17.69$ (s, 1H, OH).

${ }^{13} \mathrm{C}$ NMR $\left(75 \mathrm{MHz}, \mathrm{CDCl}_{3}, \delta, \mathrm{ppm}\right): 29.9\left(\mathrm{CH}_{3}\right), 101.26(\mathrm{C}-3), 126.5\left(\mathrm{C}_{5}\right), 125.1\left(\mathrm{C}_{6}\right), 121.2$ $\left(\mathrm{C}_{8}\right), 125.6\left(\mathrm{C}_{7}\right), 150.5\left(\mathrm{C}_{9}\right), 127.6\left(\mathrm{C}_{10}\right), 154.6(\mathrm{C}-2), 159.8(\mathrm{C}-4), 178.5(\mathrm{CO})$.

MS $(m / z,(\%)): 204\left(\mathrm{M}^{+}, 100\right), 189(74), 161(43)$.

\section{Stability constant measurements}

The stability constants $\beta x y$, being the concentration ratios $\left[M_{x} L_{y}{ }^{x n+}\right] /\left[M^{n+}\right]^{x}[L]^{y}$ and corresponding to the general equilibrium:

$\mathrm{yL}+\mathrm{xM}^{\mathrm{n}+} \rightleftarrows \mathrm{M}_{\mathrm{x}} \mathrm{L}_{\mathrm{y}}{ }^{\mathrm{xn}+}$ (where $\mathrm{M}^{\mathrm{n}+}=$ metal ion, $\mathrm{L}=$ ligand), were determined in acetonitrile and methanol by $\mathrm{UV}$-absorption spectrophotometry at $25^{\circ} \mathrm{C}$.

The ionic strength was maintained at $0.01 \mathrm{~mol} / \mathrm{L}$ using $\mathrm{Et}_{4} \mathrm{NCl}$. The spectra of the ligand solutions of concentrations ranging between $1 \times 10^{-5}$ and $4 \times 10^{-5} \mathrm{~mol} / \mathrm{L}$ and increasing concentrations of metal ion were recorded between 220 and $460 \mathrm{~nm}$. Generally, the metal to ligand ratio $R$ at the end of the titration did not exceed 20 and the equilibria were quasiinstantaneous for all the systems. Addition of the metal salts to the ligand induced spectral changes large enough to allow for the analysis of the resulting data using the program "Letagrop" 28 . Best values for the formation constants $\beta$ xy of the various complex species and their molar absorptivity coefficients for various wavelengths are deduced from the best fit between the experimental and calculated UV spectra. 
The best fit is reflected by the lowest value of $U$ (the sum of $U$ values for all given lambda) corresponding to the square sum of the differences between experimental and calculated absorbances $\left(U=\sum\left(\mathrm{A}_{\mathrm{cal}}-\mathrm{A}_{\exp }\right)^{2}\right)$. The $\beta$ xy values correspond to the arithmetic means of at least three independent experiments ${ }^{29-31}$.

\section{Extraction studies}

The extraction experiments of alkali, alkaline earth, transition metal picrates from water into dichloromethane, were performed according to a procedure described in the literature ${ }^{32-33}$. Equal volumes $(5 \mathrm{~mL})$ of a neutral aqueous solution of alkali metal picrate $\left(3 \times 10^{-4} \mathrm{~mol} / \mathrm{L}\right)$ and a solution of heterocyclic amine $\left(3 \times 10^{-4} \mathrm{~mol} / \mathrm{L}\right)$ in $\mathrm{CH}_{2} \mathrm{Cl}_{2}(5 \mathrm{~mL})$ were mixed, magnetically shaken in a thermo-regulated water bath at $25^{\circ} \mathrm{C}$ for $30 \mathrm{~min}$, and then left standing for 2 to $6 \mathrm{~h}$ in order to obtain a complete separation of the two phases. The concentration of metal picrate remaining in the aqueous phase was determined from the absorbance (A) at $\lambda=355 \mathrm{~nm}$. The percentage extraction $(\% \mathrm{E})$ was derived from the following expression in which $\mathrm{A}_{0}$ is the absorbance of the aqueous solution of a blank experiment without heterocyclic amine:

$\% \mathrm{E}=100\left(\mathrm{~A}_{0}-\mathrm{A}\right) / \mathrm{A}_{0}(1)$

\section{Conductometric studies}

While complexation by a neutral ligand is not expected to dramatically alter the molar conductivity of a cationic species, the differences can usually be detected, and so the measurement of conductance of a solution of a ligand into which a metal ion is added can be a useful rapid means of establishing the stoichiometry of a complex ion species. Thus, this procedure was followed to obtain preliminary estimates of the metal:ligand ratio in the complexes formed by the heterocyclic compound.

\section{References}

1- J. R. Dimmock, P. Kumar, Curr. Med. Chem. 1997, 4, 1-22.

2- H. I. Gul, T. Ojanen, O. Hanninen; Biol. Pharm. Bull. 2002, 25, 1307-1310.

3- H. I. Gul, T. Ojanen, J. Vepsalainen, M. Gul, E. Erciyas, O. Hanninen ; Arzneimittelforschung, 2001, 51, 72-75.

4- F. Gul, M. Gul, S. Ozturk, K. O. Yerdelen, Arch. Pharm. (Weinheim), 2005, 338, 335-338.

5- E. Mete, C. Ozelgul, C. Kazaz, D. Yurdakul, F. Sahin, H. I. Gul, Arch. Pharm. Chem. Life Sci., 2010, 343, 291-300.

6- H. I. Gul, M. Gul, E. Erciyas, J. Appl. Toxicol., 2003, 23, 53-57.

7- M. Gul, H. I. Gul, U. Das, O. Hanninen, Arzneimittelforschung, 2005, 55, 332-337.

8- H. I. Gul, K. O. Yerdelen, M. Gul, U. Das, B. Pandit, P. K. Li, H. Secen, F. Sahin, Arch. Pharm. (Weinheim), 2007, 340, 195-201.

9- H. I. Gul, U. Das, B. Pandit, P. K. Li, Arzneimittelforschung, 2006, 56, 850-855.

10-H. I. Gul, K. O. Yerdelen, U. Das. M. Gul, B. Pandit, J. R. Dimmock, Chem. Pharm. Bull. (Tokyo), 2008, 56, 1675-1681.

11-M. Gul, E. Mete, M. Atalay, M. Arik, H. I. Gul, Arzneimmittelforschung, 2009, 59, 364-369.

12-E. Mete, H. I. Gul, R. Cetin-Atalay, U. Das, E. Sahin, M. Gul, C. Kazaz, J. R. Dimmock, Arch. Pharm. Chem. Life Sci., 2011, 344, 333-339. 
13- K. Kucukoglu, M. Gul, M. Atalay, E. Mete, C. Kazaz, O. Hanninen, H.I. Gul, F. Arzneim. Drug Res. 2011, 61, 366-371.

14-H. T. Chen, Y. K. Z. Z. Jing, Ji, B. F. Zhang, Arzneim. Forsch. Drug Res., 1991, 26, 183 192.

15- H.I. Gul, F. Sahin, M. Gul, S. Ozturk, K.O. Yerdelen, Arch. Pharm. (Weinheim) 2005, 338, 335-338.

16-H. Suleyman, H. I. Gul, M. Gul, M. Alkan, F. Gocer, Biol. Pharm. Bull., 2007, 30, 63-67.

17-H. I. Gul, H. Suleyman, M. Gul, Pharm. Biol., 2009, 47, 968-972.

18. H. I. Gul, U. Calis, J. Vepsalainen, Arzneimittelforschung, 2004, 54, 359-364.

19-H. I. Gul, U. Calis, Z. Ozturk, E. Tutar, L. Calikiran, Arzneimittelforschung, 2007, 57, 133-136.

20-P. Canturk, K. Kucukoglu, Z. Topcu, M. Gul, H. I. Gul, Arzneimmittelforschung 2008, $58,686-691$.

21-E. Mete, H. I. Gul, P. Canturk, Z. Topcu, B. Pandit, M. Gul, Naturforsch C, 2010， 65c, 647-652.

22-M. Mauro, N. Erika, M. Mariangela, B. Alessandro, F. Marco, M. Marco, P. Sabrina, C. Paolo, M. Fabio, I. Cristina, L. Roberta, Bioorganic \& Medicinal Chemistry, 16, 2008, 2591-2605.

23-V. N. Dholakia, M. G. Parekh, N. K. Trivedi, Aust. J. Chem., 1968, 2, 2345-2347.

24- N. Hamdi, F. Bouabdallah, A. Romerosa. R. Benhassen, C.R.Chimie 13, 2010, 1261-1268.

25-N. Hamdi, R. Sakellariou, V. J. Speziale, Heterocycl. Chem.,1992, 29, 1817.

26-N. Hamdi, C. Fischmeister, P. Carmen, P. Valerga, Med. Chem. Res., DOI 10. 1007/s00044-010-9326-1.

27-P. J. Huang, D. Youssef, T. S. Cameron, ARKIVOC, 2008, 16, 165-177.

28-A. Ben Othman, L. Baklouti, R. Abidi, J. Vicens, Lett. Org. Chem., 2007, 4, 339-343.

29-W. J. Hao, B. Jiang, S. J. Tu, X. D. Cao, S. S. Wu, S. Yan, X. H. Zhang, Z. G. Han, F. Shi, Org. Biomol. Chem., 2009, 7, 1410-1414.

30-G. Sillen, B. Warnquist, Ark. Kemi., 1968, 31, 377-390.

31-W. Thabet, L. Baklouti, R. Zieba, S. J. Parola, Inclusion. Phenom., 2012, 73, 135-139.

32-N. Olfa, S. Hussain, B. Lassaad, European Journal of Chemistry, 2014, 5, 339-342.

33-M. Ebru, I. Halise, B. Sinan, A. Oztekin, T. Mehmet Emin, G. Medine, K. Cavit, Molecules, 2011, 16, 4660-4671. 